\section{COLLEGE QUARTERLY AND ANNUAL MEETINGS}

Members are requested to submit papers which they would like to be considered for presentation at the College's Annual and Quarterly Meetings during 1979 .

These meetings will be held as follows:

6, 7 February (London); I, 2 May (Sheffield); 10-13 July (Exeter, Annual Meeting); and 15, 16 November (London).

If a member has a preference to be considered for any particular meeting, this should be specified as early as possible. The Committee are trying to arrange programmes several months in advance, therefore papers should be sumitted accordingly.

E. G. LuGAs

Secretary

Programmes $\mathcal{E}$ Meetings Committee

\section{COLLEGE RESEARGH ON EGT}

The Research Committee is pleased to announce that they have received the good news that the Department of Health and Social Security have granted $£ 55,800$ for their proposed survey of ECT. An advertisement for a full-time research fellow of senior rank will shortly appear in the medical and national press.

Shrma A. ManN

Secretary, Research Committee

\section{PSYGHOTHERAPY SEGTION}

An Open Meeting will be held on Wednesday, 13 December, at the Tavistock Centre, Belsize Lane, London NW3, at 8.15 p.m. Speaker: Dr. J. Peddertitle to be announced.

\title{
REVIEW OF THE MENTAL HEALTH ACT, I959: A SUMMARY OF THE WHITE PAPER
}

\author{
By Dr. Robert Bluglass \\ Consultant Forensic Psychiatrist, Midland Centre for Forensic Psychiatry, All Saints' Hospital, Birmingham
}

The White Paper (HMSO Cmnd 7320) was published on 13 September, and its proposals are stated to be based on the need to strengthen the rights and safeguard the liberties of the mentally disordered, whilst retaining a proper regard for the rights and safety of the general public and staff.

Most of the proposals were discussed in the preceding Consultative Document but a few were not, or were not fully dealt with. The most important topic here is the question of what compulsory powers, if any, are needed outside hospital.

The Wales Act 1978, if it becomes law, may alter the legislation for Wales. Part VIII (property) and Sections 127 and 128 (sex offenders) are being considered elsewhere.

\section{Chapter I}

This chapter considers what changes are needed in the definition of mental disorder and also considers the legal status and rights of informal patients.

It is intended to amend Sections 90 (deportation), 134 (withholding mail) and 141 (legal action against staff) so that they cease to apply to informal patients and so that no distinction exists between informal mentally ill patients and informal physically ill patients. (1.4)

The White Paper suggests that informal patients are not always clear about their rights, and staff may have difficulties about detaining informal patients. In order that the rights of informal patients may be more firmly safeguarded it is proposed (1.14), (i) that an informal patient on admission should receive a statement of his rights (to leave hospital; to refuse 